\title{
High School Students' Critical Thinking Skills During Online Learning in Biology: Gender Perspective
}

\author{
Hikmah Supriyati ${ }^{1,{ }^{*}}$ Djukri ${ }^{2}$ \\ ${ }^{1}$ Master of Biology Education, Faculty Mathematics and Natural Sciences, Universitas Negeri Yogyakarta, \\ Indonesia \\ ${ }^{2}$ Department of Biology Education, Faculty Mathematics and Natural Sciences, Universitas Negeri Yogyakarta, \\ Indonesia \\ *Corresponding author. Email: hikmahsupriyati@gmail.com,
}

\begin{abstract}
This research was conducted during the COVID-19 pandemic with online learning. This research aims to determine the correlation between gender and students' critical thinking skills in online learning. The subjects of this study were students of SMA Islam Terpadu Ikhsanul Fikri Magelang, Central Java in the academic year 2020/2021. The sampling technique was by using cluster random sampling. Critical thinking skills data were colected using essay questions that were tested on 63 students. The analysis Technique was descriptively quantitative. The results of this study indicate that there are differences in critical thinking skills levels between male and female student during online learning. The results of the correlation test in this study showed a value of 0.378 , which means that the effect of the gender variable on the critical thinking skills of class XI high school students in Biology subjects is in the low category. Female students score higher than male students on all aspects of critical thinking.
\end{abstract}

Keywords: Critical thinking, Online learning, Gender.

\section{INTRODUCTION}

More than 200 countries with millions of people in the world have infected Coronavirus Disease or COVID-19 [1]. The World Health Organization (WHO) has pronounced COVID-19 a worldwide pandemic on March 11, 2020 [2]. The impact of the spread of COVID-19 is now also felt by the education world [3]. Various policies have been carried out by the Indonesian government to break the chain of distribution of the covid-19 virus. The education sector has issued a policy through Circular Number 4 of 2020 concerning Implementation of Education Policies in an Emergency for the Spread of COVID [4]. The existence of this policy requires that the learning process be carried out at home through online/distance learning.

During online learning teaching and learning activities can be reached from various times and places [5]. This is because o nline learning requires students and educators to take advantage of technology. The use of technology in learning is in accordance with the 2013 curriculum principles that have been implemented by the Indonesian state. According to Regulation of the Minister of Education and Culture No. 65 of 2013, the 2013 curriculum principles are also related to the use of information and communication technology to increase the efficiency and effectiveness of learning [6].

The online learning experienced by the Indonesian people today is in line with the demands of the Industrial Revolution 4.0 era. In this era, the industry has begun to contact the virtual world, in the form of human, machine and data connectivity, everything is everywhere, or known as the Internet of Things (IoT) [7]. The existence of the 4.0 industrial revolution made the world is now experiencing changes that are increasingly fast and competitive. In this era, various information can be accessed and searched very easily [8]. An important competency that every individual must have in the era of globalization is critical thinking [9]. 
Critical thinking is reasonable and reflective thinking that focuses on deciding what to believe or do[10]. Critical thinking is not a natural trait or personality, but about a set of methods that aim to explore evidence in a particular way, namely cognitive activities related to the use of the mind, processes that rely on and develop various skills and personal qualities [11]. Through this critical thinking, everyone can improve their reasoning skills in dealing with daily problems[12].

There are indicators that affect students' critical thinking skills, either directly or indirectly. Gender differences are one of the roundabout factors that influence critical thinking skills. Men and women are not only physically different but also emotionally and intellectually different[13]. Gender differences will cause physiological differences, which also affect psychological differences in learning [14]. Mahanal revealed that there is a gender influence on critical thinking skills [15].

Various studies on the effect of gender on critical thinking skills have been investigated. However, there is still no research that addresses the critical thinking skills of students with online learning experiences based on gender. Seeing this, the researcher was interested in knowing the gender relationship with the critical thinking skills of high school students through online learning. Furthermore, researchers are also interested in knowing whether there is a difference in critical thinking skills among female and male students.

\section{MATERIALS AND METHODS}

This research is a quantitative descriptive study to decide the differences in critical thinking skills of female and male students. The instrument used to measure students' critical thinking skills in the form of essay questions. The questions used consisted of 5 questions with critical thinking aspects, namely advanced clarification, bases for a decision, inference, strategy and tactics, basic clarification, [10].

The instrument is made based on the aspect of critical thinking skills which is first consulted with the Biology teacher. Furthermore, the validity test was carried out by testing the instrument on 35 students. The validity test is used to measure whether an instrument item is valid or not. Test is done by calculating the correlation among the score of each question item and the absolute score [16]. The results of the validity test can be seen in Table 1 . From table 1 it can be seen that $r$ count is greater than $r$ table (0.334). While the significance value is less than 0.05 . It tend to be concluded that all questions on critical thinking skills are valid.

Table 1. The validity results of students' critical thinking skills

\begin{tabular}{|c|c|c|c|c|c|c|c|}
\hline & & P1 & P2 & P3 & P4 & P5 & Total \\
\hline \multirow[t]{3}{*}{ P1 } & $P C$ & 1 & $0.678^{* *}$ & $0.499^{* *}$ & $0.553^{* *}$ & 0.051 & $0.772^{* *}$ \\
\hline & Sig.(2-tailed) & & 0.000 & 0.002 & 0.001 & 0.772 & 0.000 \\
\hline & $\mathrm{N}$ & 35 & 35 & 35 & 35 & 35 & 35 \\
\hline \multirow[t]{3}{*}{$\mathrm{P} 2$} & $P C$ & $0.678^{* \star}$ & 1 & $0.389^{*}$ & $0.484^{* *}$ & 0.207 & $0.756^{* *}$ \\
\hline & Sig.(2-tailed) & 0.000 & & 0.021 & 0.003 & 0.232 & 0.000 \\
\hline & $\mathrm{N}$ & 35 & 35 & 35 & 35 & 35 & 35 \\
\hline \multirow[t]{3}{*}{ P3 } & PC & $0.499^{* *}$ & $0.389^{*}$ & 1 & $0.406^{*}$ & 0.275 & $0.772^{* *}$ \\
\hline & Sig.(2-tailed) & 0.002 & 0.021 & & 0.016 & 0.110 & 0.000 \\
\hline & $\mathrm{N}$ & 35 & 35 & 35 & 35 & 35 & 35 \\
\hline \multirow[t]{3}{*}{ P4 } & $P C$ & $0.553^{* *}$ & $0.484^{* *}$ & $0.406^{*}$ & 1 & $.0345^{*}$ & $0.755^{* *}$ \\
\hline & Sig.(2-tailed) & 0.001 & 0.003 & 0.016 & & 0.042 & 0.000 \\
\hline & $\mathrm{N}$ & 35 & 35 & 35 & 35 & 35 & 35 \\
\hline \multirow[t]{3}{*}{$\mathrm{P5}$} & $P C$ & 0.051 & 0.207 & 0.275 & $0.345^{*}$ & 1 & $0.507^{\star \star}$ \\
\hline & Sig.(2-tailed) & 0.772 & 0.232 & 0.110 & 0.042 & & 0.002 \\
\hline & $\mathrm{N}$ & 35 & 35 & 35 & 35 & 35 & 35 \\
\hline Total & $P C$ & $0.772^{* *}$ & $0.756^{* *}$ & $0.772^{* *}$ & $0.755^{* *}$ & $0.507^{* *}$ & 1 \\
\hline
\end{tabular}




\begin{tabular}{|l|l|l|l|l|l|l|l|}
\hline & Sig.(2-tailed) & 0.000 & 0.000 & 0.000 & 0.000 & 0.002 & \\
\hline & $\mathrm{N}$ & 35 & 35 & 35 & 35 & 35 & 35 \\
\hline
\end{tabular}

Furthermore, the reliability test is carried out. The reliability test was carried out with the help of the SPSS 16.0 program using the Cronbach Alpha $(\alpha)$ facility. A variable is expected to be reliable on the off chance that it gives a Cronbach Alpha value> 0.60 [16]. The results of the calculation of the reliability test can be found in table 2. The results of Cronbach Alpha $(\alpha)$ for the critical thinking skills variable are 0.751 . Thus it tend to be deduce that the variable/construct of critical thinking skills is reliable.

Table 2. The reliability test results

\begin{tabular}{|c|c|}
\hline $\begin{array}{l}\text { Cronbach's } \\
\text { Alpha }\end{array}$ & N of Items \\
\hline 0.751 & 5 \\
\hline
\end{tabular}

The sampling technique was done by using cluster random sampling. The subjects of this study were understudies of class XI SMA Islam Terpadu Ikhsanul Fikri Magelang, Central Java in the academic year 2020/2021. SMA Islam Terpadu Ikhsanul Fikri class grouping based on gender, where male and female classes are made separate. The sample consisted of 63 students with 30 male students (XI MIPA 2) and 33 female students (XI MIPA 4). The data on students' critical thinking skills were then tested on the prerequisite test, namely normality and homogeneity test. Data analysis used the Phi Coefficient Correlation with SPSS. The Phi Correlation Technique is one of the correlational analysis techniques used when the correlated data is truly dichotomic data (separated or sharply separated), such as men and women, dead and alive and others. Basically, Phi is the Product moment correlation. The Phi Coefficient can be interpreted in the same way as the $r$ Product Moment of the person. This test was directed o decide whether or not there was a significant correlation among gender and students' critical thinking skills [17].

\section{RESULTS AND DISCUSSION}

This research was conducted during the COVID19 pandemic with online learning. This research aims to determine whether there is a correlation among gender and students' critical thinking skills in online learning, as well as to determine whether gender relations with critical thinking skills are negative or positive. The statistical test in this study used SPSS, namely the person correlation test. Person correlation test is performed after the data is known to be normally distributed and homogeneous. Homogeneity and normality data were tested using the SPSS For Windows series 16 program [18]. The normality test can be found in table 3 .

Table 3. Normality test results

\begin{tabular}{|l|l|l|l|l|}
\hline \multirow{2}{*}{} & \multirow{2}{*}{ Gender } & \multicolumn{3}{|c|}{ Kolmogorov-Smirnov } \\
\cline { 3 - 5 } & & Statistic & df & Sig. \\
\hline \multirow{2}{*}{$\begin{array}{l}\text { Critical } \\
\text { Thinking }\end{array}$} & 1 & 0.146 & 30 & 0.100 \\
\cline { 2 - 5 } & 2 & 0.123 & 33 & $0.200^{*}$ \\
\hline
\end{tabular}

The normality test used in this research is the Kolmogorov-Smirnov Test. The normality test is done to decide whether the data is normally distributed or not. If the significance value is greater than 0.05 , the sample is normally distributed [19]. From the Kolmogorov-Smirnov table, it is known that the significance (sig) value is 0.2 and 0.1 , thus it can be concluded that the sample comes from a normally distributed populace. Table 4 shows the results of the homogeneity test.

Table 4. Homogeneity test results

\begin{tabular}{|l|l|l|l|}
\hline Levene Statistic & df1 & df2 & Sig. \\
\hline 0.114 & 1 & 61 & 0.737 \\
\hline
\end{tabular}

This test aims to determine whether or not the variance of the sample is uniform. The results of the homogeneity test in this study, it is known that the significance value is 0.737 . The significance value is greater than 0.05 , so the sample comes from a population with the same variance. The results of prerequisite testing, it can be seen that the data in this study are normally distributed and homogeneous. Furthermore, the person correlation test is carried out to determine whether or not there is a correlation between gender and critical thinking skills. The results of the person correlation test can be seen in the following table:

Table 5. Pearson correlation (PC) test results.

\begin{tabular}{|l|l|l|l|}
\hline & & Gender & $\begin{array}{l}\text { Critical } \\
\text { Thinking }\end{array}$ \\
\hline Gender & PC & 1 & $0.378^{* *}$ \\
\hline
\end{tabular}




\begin{tabular}{|l|l|l|l|}
\hline \multirow{7}{*}{} & $\begin{array}{l}\text { Sig. (2- } \\
\text { tailed) }\end{array}$ & & 0.002 \\
\cline { 2 - 4 } & $\mathrm{N}$ & 63 & 63 \\
\hline \multirow{7}{*}{$\begin{array}{l}\text { Critical } \\
\text { Thinking }\end{array}$} & PC & $0.378^{* *}$ & 1 \\
\cline { 2 - 4 } & $\begin{array}{l}\text { Sig. (2- } \\
\text { tailed) }\end{array}$ & 0.002 & \\
\cline { 2 - 4 } & $\mathrm{N}$ & 63 & 63 \\
\hline
\end{tabular}

From table 5 , it can be seen that the significance (sig) value obtained is 0.002 . These results indicate that there is a correlation between gender and critical thinking skills in online learning. These results are in line with the conclusions of research conducted by Ghadi, Bakar, Alwi, and Thalib that gender affects critical thinking skills, although not significantly [20]. A study conducted by Wardani, Wahyu, et al, the results show that there is an influence between gender on critical thinking skills [13].The results of the correlation test analysis in this study also shows how big the correlation between gender and students' critical thinking skills. As for the classification of the correlation coefficient, namely [21]:

Table 6. Classification of correlation coefficients.

\begin{tabular}{|l|l|}
\hline Correlation Coefficient & Classification \\
\hline$<0.20$ & Very low \\
\hline $0.20-0.40$ & Low \\
\hline$>0.40-0.70$ & Medium \\
\hline$>0.70-0.90$ & High \\
\hline$>0.90-1.00$ & Very High \\
\hline
\end{tabular}

The results of the correlation test in this research showed a value of 0.378 , which means that the influence between gender variables and the critical thinking ability of Class XI SMA Islam Terpadu Ikhsanul Fikri students in Biology subjects is in the low category (Table 6). The correlation coefficient value in the statistical test is positive, meaning that the higher the gender score, the higher the students' critical thinking skills. Gender in this study is symbolized by nominal values, namely one for men and two for women. The difference in the average value of female and male students' critical thinking skills can be seen in Figure 1.

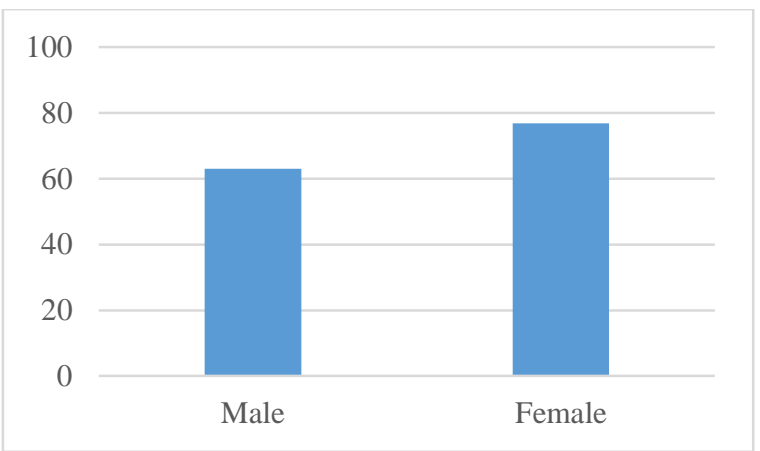

Figure 1 The average score of students' critical thinking

From the Figure 1, it can be seen that there is a difference in the average critical thinking score of female and male students. The results showed that male students have not better abilities than female students in critical thinking. Female students have an average score of 76.9, while male students have an average score of lower critical thinking skills, namely 63. This is accordance with the research conducted by Halpern and LaMay which found differences in intelligence and individual activities between men and women [22]. Besides influencing physical differences, gender also affects students' thinking abilities, especially critical thinking skills. One of the factors causing these differences is the difference in intelligence. Mahanal clarified that female understudies have higher critical thinking ability than male understudies [23]. The results of research conducted by Butler et al show that female students have better abilities than male students in critical thinking [24]. According to Fahim \& Bagheri, gender differences have been shown to contribute to critical thinking skills scores [25].

This study measures five spects of critical thinking skills according to the theory of Reeder $\mathrm{H}$ namely strategy and tactics, basic clarification, inference, bases for a decision, advanced clarification, [10]. From all the aspects that have been measured, it can be seen that female students score higher on all aspects of critical thinking than male students. This is in consisted with Walsh \& Hardy who reported that female students scored higher on all aspects of critical thinking than male students [26]. According to Heijltjes et al, stated that relating to the brain's anatomy of males and females, men have more developed brains and have more complex abilities in planning, memorizing direction, abstraction, and visualization. A male has a brain with the area of cortex working on spatial functions more so that the ability of a man to produce and process words becomes less. Meanwhile, the female has a corpus 
callosum, which is four times larger than man, so that a man cannot focus on more works at the same time [27].

Table 7. The average score of each aspects of critical thinking skills on students.

\begin{tabular}{|l|l|l|l|l|l|}
\hline \multirow{2}{*}{} & \multicolumn{4}{|l|}{ The Aspect of Critical Thinking Skills } \\
\cline { 2 - 6 } & Advanced Clarification & Bases for a Decision & Inference & Basic Clarification & Strategy and Tactics \\
\hline Male & 2.63 & 2.1 & 2.76 & 2.66 & 2.43 \\
\hline Female & 3.36 & 2.93 & 3.03 & 3.27 & 2.78 \\
\hline
\end{tabular}

\section{CONCLUSION}

Based on the results of this study, it can be deduced that there is a low correlation between gender and critical thinking skills during online learning. The results of the correlation test in this study showed a value of 0.378 , which means that the effect of the gender variable on the critical thinking skills of class XI MIPA students are in a low category. From all aspects that have been measured, it can be seen that female students score higher on all aspects of critical thinking than male students.

\section{REFERENCES}

[1] M.A. Shereen, Khan S Kazmi A Bashir N, Siddique R, COVID-19 Infection: Origin, Transmission, and Characteristics of Human Coronaviruses, Journal of Advanced Research. 24 (2020) 91-98. DOI: https://doi.org/10.1016/j.jare.2020.03.005

[2] D. Cucinotta, M. Vanelli, WHO Declares COVID-19 A Pandemic, Acta Biomed, 91(1) (2020) 157-160. DOI: https://doi.org/10.23750/abm.v91i1.9397

[3] M.B.N. Wajdi, et.al., Education Policy Overcome Corona Virus, A Study of Indonesians, Jounal Education and Technology 3(2) (2020) 97.9 DOI: https://doi.org/10.29062/edu.v3i2.42

[4] Regulation of the Minister of Education and Culture No. 4 of 2020 Concerning The Implementation of Education in The Emergency Coronavirus Disease (Covid-19), Jakarta, 2020.

[5] T. Shukla, et.al., Factors Extraction of Effective Teaching-Learning in Online and Conventional Classrooms, Internasional Journal of Information and Education Technology 10(6) (2020) 422
427.

DOI:

https://doi.org/10.18178/ijiet.2020.10.6.1401

[6] Regulation of the Minister of Education and Culture Number 65 of 2013 Concerning Process Standards, Jakarta, 2013.

[7] D. Lase, Pendidikan di Era Revolusi Industri 4.0, Jurnal Sundermann 1(1) (2019) 28-43. DOI: https://doi.org/10.36588/sundermann.v1i1.18

[8] A.R. As'ari, Ideas for Developing Critical Thinking at Primry School Level, in: International Seminar on Addressing Higher Order Thinking: Critical Thinking Issues in Primary Education, Islamic University of Muhammadiyah Makasar, 2014, pp. 1-13.

[9] F. Kalelioğlu, Y. Gülbahar, The Effect of Instructional Techniques on Critical Thinking and Critical Thinking Dispositions in Online Discussion, Educational Technology Society 17(1) (2014) 248-258.

[10] H.R. Ennis, The Nature of Critical Thinking: An Outline of Critical Thinking Dispositions and Abilities Informal, 2011.

[11] S. Cottrell, Critical Thinking Skills: Developing Effective Analysis and Argument (Palgrave Study Skills) 2nd Edition Palgrave Macmillan; 2nd Edition, 2011.

[12] M. Hayudiyani, M. Arif, M. Risansari, Identifikasi Kemampuan Berpikir Kritis Siswa Kelas X, Jurnal Ilmiah Edutic 4(2) (2017). DOI: https://doi.org/10.21107/edutic.v4i1.3383

[13] W. Wardani, I K. Astina, S. Susilo, Pengaruh Gender terhadap Kemampuan Berpikir Kritis Siswa SMA Program IPS pada Mata Pelajaran Geografi, Jurnal Pendidikan 3(12) (2018) 15301534.

[14] Z.A. MZ, Perspektif Gender dalam Pembelajaran Matematika, Marwah Jurnal Perempuan, Agama 
dan Jender 12(1) (2013) 15. DOI:http://dx.doi.org/10.24014/marwah.v12i1.5 11

[15] S. Mahanal, Strategi Pembelajaran Biologi, Gender dan Pengaruhnya terhadap Kemampuan Berpikir Kritis, in: Proceding Conference on Pendidikan Biologi FKIP UNS, UNS, 2012, pp. 691-697.

[16] D. Sunyoto, Chi-Square Test and Regression for Research, Graha Ilmu, 2010.

[17] A. Sudjiono, Introductional to Educational Statistics, Rajawali Press, 2012.

[18] S. Santoso, SPSS Master Version 19, Elex Media Komputindo, 2011.

[19] Budiyono, Statistics for Research, UNS Press, 2009.

[20] I.N. Ghadi, et al., Gender Analysis of Critical Thinking Disposition Instrument among University Putra Malaysia Undergraduate Students, Recent Technological Addvances in Education (2008) 27-33.

[21] J. Sarwono, Quantitative and Qualitative Research Methods, Graha Ilmu, 2006.

[22] D.F. Halpern, M.L. LaMay, The Smarter Sex: A Critical Review of Sex Differences in Intelligence, Educational Psychology Review, 12 (2000) 229-246. DOI:https://doi.org/10.1023/A:1009027516424

[23] S. Mahanal, Pengaruh pembelajaran berbasis proyek pada matapelajaran biologi kritis, dan gender terhadap keterampilan metakognisi dan kemampuan berpikir siswa sma di malang, vol. 1, in: Proceding Conference on Pendidikan IPA Pascasarjana Universitas Malang, Universitas Negeri Malang (UM), 2016, pp. 748-755.

[24] H.A. Butler, C.Pentoney, M.P. Bong, Predicting Real-World Outcomes: Critical Thinking Ability Is A Better Predictor of Life Decisions Than Intelligence, Thinking Skills and Creativity 25 (2017) 38-46. DOI: https://doi.org/10.1016/j.tsc.2017.06.005

[25] M. Fahim, M.B. Bagheri, Fostering Critical Thinking through Socrates' Questioning in Iranian Language Institutes, Journal of Language Teaching and Research 3(6) (2012) 1122-1127. DOI:https://doi.org/10.4304/jltr.3.6.1122-1127

[26] C.M. Walsh, R.C. Hardy, Dispositional Differences in Critical Thinking Related to Gender and Academic Major, Journal of Nursing Educational 38(4) (1999) 149-155. PMID: 1022526

[27] A. Heijltjes, T. van Gog, J. Leppink, F. Paas, Improving Critical Thinking: Effects of Dispositions and Instructions Oneconomics Students' Reasoning Skills, Learning and Instruction 29 (2014) 31-42. DOI: https://doi.org/10.1016/j.learninstruc.2013.07.00 $\underline{3}$ 